\title{
(Literature Review) \\ The Conceptual Confusion of Teaching Quality and Teacher Quality, and a Clarity Pursuit
}

\author{
Awuradjoa Aidoo $1 *$ https://orcid.org/0000-0003-3092-1284, Luo Shengquan ${ }^{2}$ \\ 1,2Southwest University, China \\ *e-mail: *awuradjoadjirba.aa@gmail.com
}

\section{Article Information}

Received: March 06, 2021

Revised: April 2, 2021

Accepted: April 2, 2021

Online: May 11, 2021

\section{Keywords}

conceptual confusion, conceptual analysis, conceptual clarity, teaching quality, teacher quality

\section{INTRODUCTION}

Referred to as instructional quality (Rjosk et al., 2014), teaching quality (Arnold, 2011), teaching effectiveness ( Seidel \& Shavelson, 2007), and teacher quality (Zablotsky \& Rosenberg, 2013), together based on collective consensus for and against what these terms entail, forms a phenomenon that has been termed 'conceptual confusion' (Murphy \& Alexander, 2000; Tahtinen \& Havila, 2019), and that Ruiz-Alfonso and Leon (2019): describe as a case of a variety of terms denoting similar ideas, and Tahtinen \& Havila (2019) as: 
Studies focused on the same phenomenon, using various labels and terms to refer to the phenomenon or its experiences, without explicit definitions or descriptions. In addition, some different concepts are defined similarly, and some same definitions relate to more than one concept. (p.534)

Teaching quality (TgQ) has been assigned many definitions (Henard, 2010; Monsegue-Bailey, 2018) and is contended by Wang et al. (2011) as yet to be given a clear definition. The term has also been identified to replace teacher quality (TrQ), and vice versa, in literature (Churchward \& Willis, 2018). This practice has implications for further and detailed study into the individual concepts, serving as obstacles to comprehend their dimensions, components, definitions, measurement, influential impact, development, input sources, differences, and related informing topics. However, this issue lacks critical investigation and is not given much research attention- the problem is only sparsely mentioned superficially, and in passing, in a few works. This situation informed the need for further examination of the intricacies of the two concepts in order to reach an insightful conclusion as to their demarcated differences, for meaningful contribution to practice such as: enabling required professional development needs identification for teachers (Hill et al., 2012); clarification of the appropriate areas for leadership coaching and mentoring; and providing personal awareness for teachers, giving them the chance to invest and grow in their chosen profession. Then with these in motion, teachers could have value-added developments, the education and schools can improve (Mincu, 2015), and student achievement can be positively impacted (Hattie, 2009; Rice, 2003). Then also, the distinction of the two concepts would assist in practice, with the placement of the concepts in the context of the educational system in accounting for school factors such as school climate, for action research purposes; as well as allowing the possibility to utilize the relationship modeling technique in checking for indicators between these concepts and student outcomes in different subjects, especially in cases of cross-cultural comparisons, (Nilsen \& Gustafsson, 2016).

The study searched six databases, namely: ERIC, ScienceDirect, JSTOR, Sage Journals, Sage Knowledge, and Web of Science for articles on teaching quality, and teacher quality, with the keywords: teacher quality; teaching quality, and differences between teacher quality and teaching quality. The study also searched Google Scholar and used the Google search engine to search randomly for articles and books on conceptual confusion, teacher quality, and teaching quality, with the keywords: conceptual confusion, teaching quality, and teacher quality. The search process began in September 2020 to March 2021. The majority of the selected articles were published within the last ten years; however, the selection was not made with the emphasis on restriction of publication period because the study wanted to investigate the practice of the interchangeable use of the concepts with time and the articles' publication time places no limit on this purpose.

The articles were scanned to find authors' perceptions and contributions to the topics with a structured examination of the needed content areas. It involved skimming through the materials, emphasizing the subheadings as a guide, ascertaining the main areas the arguments of interest were located, and their preceding and following preliminary and conclusive related discussions. Findings on perceptions and impressions were noted, and unique concepts in the books and articles central to a comprehensive understanding of the topic were extracted. Then the selected areas were explored in detail by deliberating on the meaning and implication of their content concerning the observed practice of conceptual confusion. It was followed by a summary of the relevant information from each source: the information was checked for possible patterns, consistency in the information provided, and disagreements against positions and claims among the scholars. This information was then tabulated, drafted into diagrams, and is presented in the following sections. These actions also assisted us in connecting the different information from various sources in a consolidated and coherently meaningful way. Cited references in the selected articles were also examined by following up on sources with related topics to probe the topic further.

\section{Teacher Quality: A Concept with Many Perspectives}

TrQ is at times referred to with the descriptions, teacher qualification (Darling-Hammond, 2000), subject matter knowledge, experience (Fitchett \& Heafner, 2018), psychological characteristics embodying teacher's inward attributes, intellectual capabilities, and distinctive traits (Rimm-Kaufman 
\& Hamre, 2010), degree level, certification, pedagogical content knowledge, professional knowledge, and teacher preparation, (Perez, 2013). See details in Table 1. Perez, for instance, again identifies TrQ in its use as a description of the person(teacher): with the function here identified to be an adjective, thereby placing the term as a modification of the individual- that drives student learning and describes $\operatorname{TgQ}$ as the verb (thereby conveying the occurrence or action practiced by the teacher), that drives student learning.

Such distinction offered by Perez leads us to one of the approaches to distinguish the two concepts, which is through the consideration of 'teacher' in teacher quality as a person/personality (noun), and 'teaching' in TgQ as a (verb) an action of measurement (to measure teacher actions toward student learning), as her definition stipulates. It is also suggestive of the role the concept plays in theory and its relationship: an existent dialogue with TrQ, signaling accuracy in the association and use of the conception. This elucidation helps to not only explain TgQ, but also to show an existing relationship with TrQ. We have observed those semantics as feature functions to distinguish between the terms on very basic and straightforward levels. Furthermore, the principle of semantic compositionality, on the level of phrasal meaning being derived from the meaning of constituent parts (Pelletier, 1994), could be employed for an emphatical explanation.

\section{Teaching Quality: What It Is, and What It May Not Be}

According to the research of several authors, $\mathrm{TgQ}$ is mainly related to teaching approaches and activities, while others also approach $\operatorname{TgQ}$ through dimensional description and ascriptions. From other angles, scholars are known to describe $\operatorname{TgQ}$ by the elements of teaching that impact students' intellectual and emotional achievement, with other angles being the quality of the actual pedagogical process of teaching in the classroom. Then, dimensions, for instance, considered in establishing TgQ vary even in content and per different authors' views, ranging from: climate; management; student engagement, content matter exposition, cognitive alertness, learning assessment, differentiated teaching, and teaching, learning, and self-regulation.

These dimensions' content further varies in associated elements as well. See details in Table 1. All these descriptions, definitions, and interpretations of TgQ touch on diverse areas of education and/but establish one thing; these authors view $\operatorname{TgQ}$ from varied angles and perspectives.

Table 1. Conceptual analysis of teaching quality and teacher quality among scholars

\begin{tabular}{|c|c|c|c|c|}
\hline Index & Teaching Quality & Author & Teacher Quality & Author \\
\hline \multirow[t]{2}{*}{ Inputs } & $\begin{array}{l}\text { Beliefs, attitudes, } \\
\text { knowledge } \\
\text { introduced to the } \\
\text { teaching profession }\end{array}$ & $\begin{array}{l}\text { Wang et al. } \\
\text { (2011) }\end{array}$ & $\begin{array}{l}\text { Teacher knowledge, } \\
\text { teacher preparation, } \\
\text { related professional } \\
\text { qualifications, } \\
\text { disposition, attitude }\end{array}$ & Perez (2013) \\
\hline & Teacher performance & $\begin{array}{l}\text { Madu and Kuei } \\
\text { (1993); Kennedy } \\
\text { (2008) }\end{array}$ & & \\
\hline \multirow[t]{2}{*}{ Dimensions } & $\begin{array}{l}\text { Conducive classroom } \\
\text { climate, class } \\
\text { management, } \\
\text { engaging instruction, } \\
\text { adaptive teaching, } \\
\text { and teaching and } \\
\text { learning strategies }\end{array}$ & Bell et al. (2012) & Teacher qualification & $\begin{array}{l}\text { Darling- } \\
\text { Hammond } \\
(2000)\end{array}$ \\
\hline & $\begin{array}{l}\text { Student support, } \\
\text { classroom } \\
\text { management, and } \\
\text { cognitive activation }\end{array}$ & $\begin{array}{l}\text { Fischer et al. } \\
\text { (2019) }\end{array}$ & $\begin{array}{l}\text { Abilities, skills, attitude, } \\
\text { knowledge, teacher } \\
\text { disposition }\end{array}$ & $\begin{array}{l}\text { Mitchell et al. } \\
\text { (2001) }\end{array}$ \\
\hline
\end{tabular}




\begin{tabular}{|c|c|c|c|c|}
\hline Index & Teaching Quality & Author & Teacher Quality & Author \\
\hline & $\begin{array}{l}\text { Teachers' intellectual } \\
\text { assets, teacher } \\
\text { performance, teacher } \\
\text { results (performance- } \\
\text { effect), cognitive } \\
\text { resources (teacher } \\
\text { knowledge, } \\
\text { disposition, attitude) }\end{array}$ & Kennedy (2008) & $\begin{array}{l}\text { Skills and attitude } \\
\text { related to teaching } \\
\text { quality }\end{array}$ & $\begin{array}{l}\text { Churchward } \\
\text { and Willis } \\
\text { (2018) }\end{array}$ \\
\hline & $\begin{array}{l}\text { Affective support, } \\
\text { teaching support, } \\
\text { classroom } \\
\text { organization }\end{array}$ & $\begin{array}{l}\text { Grosse et al. } \\
\text { (2017) }\end{array}$ & $\begin{array}{l}\text { Personal development } \\
\text { (intellect, societal, } \\
\text { affective evolution), } \\
\text { professional } \\
\text { development (teacher } \\
\text { preparation, teaching } \\
\text { experience), } \\
\text { psychological } \\
\text { characteristics } \\
\text { (teachers' inward } \\
\text { attributes, intellectual } \\
\text { capabilities, distinctive } \\
\text { traits), teacher } \\
\text { experiences }\end{array}$ & $\begin{array}{l}\text { Rimm- } \\
\text { Kaufman and } \\
\text { Hamre (2010) }\end{array}$ \\
\hline \multirow[t]{2}{*}{ Dimensions } & Teaching support & $\begin{array}{l}\text { Rieser et al. } \\
\text { (2016) }\end{array}$ & $\begin{array}{l}\text { Licensure, content } \\
\text { background }\end{array}$ & $\begin{array}{l}\text { Fitchett and } \\
\text { Heafner(2018) }\end{array}$ \\
\hline & $\begin{array}{l}\text { Instructional support, } \\
\text { classroom } \\
\text { management, } \\
\text { conducive } \\
\text { environment }\end{array}$ & $\begin{array}{l}\text { Klieme et al. } \\
\text { (2009) }\end{array}$ & & \\
\hline Domains & $\begin{array}{l}\text { Affective support, } \\
\text { classroom } \\
\text { organization, } \\
\text { teaching support }\end{array}$ & $\begin{array}{l}\text { Hafen et al. } \\
\text { (2014) }\end{array}$ & Content knowledge & $\begin{array}{l}\text { Babcock et al. } \\
(2010)\end{array}$ \\
\hline \multirow[t]{2}{*}{ Definition } & $\begin{array}{l}\text { Teacher actions to } \\
\text { enhance student } \\
\text { learning in the } \\
\text { classroom }\end{array}$ & Perez (2013) & $\begin{array}{l}\text { Teacher characteristics } \\
\text { encompassing their } \\
\text { professional } \\
\text { preparation and } \\
\text { professional knowledge } \\
\text { (subject matter } \\
\text { knowledge, } \\
\text { experience, degree } \\
\text { level, certification, } \\
\text { pedagogical content } \\
\text { knowledge }\end{array}$ & Perez (2013) \\
\hline & $\begin{array}{l}\text { Teacher actions in the } \\
\text { classroom to } \\
\text { enhance student } \\
\text { learning }\end{array}$ & $\begin{array}{l}\text { Kaplan and } \\
\text { Owings (2001) }\end{array}$ & $\begin{array}{l}\text { Subject matter } \\
\text { knowledge, } \\
\text { experience, } \\
\text { professionalism to } \\
\text { teach, suitability, and }\end{array}$ & $\begin{array}{l}\text { Fitchett and } \\
\text { Heafner } \\
(2018)\end{array}$ \\
\hline
\end{tabular}




\begin{tabular}{|c|c|c|c|c|}
\hline Index & Teaching Quality & Author & Teacher Quality & Author \\
\hline & & & $\begin{array}{l}\text { adequacy of experience } \\
\text { for students }\end{array}$ & \\
\hline & $\begin{array}{l}\text { Using pedagogical } \\
\text { styles to produce } \\
\text { learning outcomes }\end{array}$ & $\begin{array}{l}\text { Henard and } \\
\text { Roseveare(2012) }\end{array}$ & $\begin{array}{l}\text { The inputs brought to } \\
\text { school by the teacher }\end{array}$ & $\begin{array}{l}\text { Kaplan and } \\
\text { Owings (2001) }\end{array}$ \\
\hline & $\begin{array}{l}\text { Teaching approaches } \\
\text { and activities } \\
\text { mirrored in } \\
\text { classroom } \\
\text { organization and } \\
\text { support for student } \\
\text { engagement }\end{array}$ & $\begin{array}{l}\text { Brophy (1999); } \\
\text { Pianta and } \\
\text { Hamre (2009); } \\
\text { Roehrig et al. } \\
\text { (2012) }\end{array}$ & $\begin{array}{l}\text { *Both teaching and } \\
\text { learning associated } \\
\text { teacher practices and } \\
\text { teacher-student } \\
\text { interactions in the } \\
\text { classroom that } \\
\text { contribute to student } \\
\text { achievement and their } \\
\text { development }\end{array}$ & $\begin{array}{l}\text { Rimm- } \\
\text { Kaufman and } \\
\text { Hamre (2010) }\end{array}$ \\
\hline & $\begin{array}{l}\text { Teacher-student } \\
\text { interactions that take } \\
\text { place in the } \\
\text { classroom }\end{array}$ & $\begin{array}{l}\text { Cornelius-White } \\
\text { (2007) }\end{array}$ & $\begin{array}{l}\text { **teacher quality- } \\
\text { informing-factors as } \\
\text { activities between } \\
\text { teachers and students } \\
\text { that bring about student } \\
\text { achievement }\end{array}$ & \\
\hline & $\begin{array}{l}\text { Defined through a } \\
\text { three-dimensional } \\
\text { description: learning } \\
\text { support, effective } \\
\text { classroom } \\
\text { management, and } \\
\text { cognitive activation }\end{array}$ & $\begin{array}{l}\text { Klieme et al. } \\
(2001)\end{array}$ & $\begin{array}{l}{ }^{* * *} \text { practical } \\
\text { instructional and } \\
\text { classroom activities, } \\
\text { behaviors, and teacher- } \\
\text { student contact that } \\
\text { yield achievement from } \\
\text { students }\end{array}$ & \\
\hline & $\begin{array}{l}\text { Elements of teaching } \\
\text { that have an impact } \\
\text { on the intellectual } \\
\text { and emotional } \\
\text { achievement of } \\
\text { students }\end{array}$ & $\begin{array}{l}\text { Seidel and } \\
\text { Shavelson } \\
(2007)\end{array}$ & & \\
\hline & $\begin{array}{l}\text { Quality of the actual } \\
\text { pedagogical process } \\
\text { of teaching in } \\
\text { classrooms }\end{array}$ & $\begin{array}{l}\text { Teacher Task } \\
\text { Force (n.d.) }\end{array}$ & & \\
\hline & $\begin{array}{l}\text { Teacher behaviors } \\
\text { responsible for } \\
\text { enhancing students' } \\
\text { educational } \\
\text { achievement }\end{array}$ & $\begin{array}{l}\text { Cochran-Smith } \\
\text { and Fries (2005) }\end{array}$ & & \\
\hline & $\begin{array}{l}\text { Practical teacher } \\
\text { activities and } \\
\text { student-teacher } \\
\text { relations that echo } \\
\text { adaptive }\end{array}$ & $\begin{array}{l}\text { Rimm-Kaufman } \\
\text { and Hamre } \\
(2010)\end{array}$ & & \\
\hline
\end{tabular}




\begin{tabular}{lllll}
\hline Index & Teaching Quality & Author & Teacher Quality & Author \\
\hline $\begin{array}{l}\text { developmental } \\
\text { regulation }\end{array}$ & & & \\
\hline
\end{tabular}

\section{Possible Sources and Causes of the Confusion}

On some reasons behind the confusion, some authors have put forward the idea that contextual differences contribute to inconsistency in TgQ patterns in different locations (Fenstermacher \& Richardson, 2005; Wang et al., 2011), with the meaning of TgQ experiences, differing in content and social contexts, cementing the notion of intrusion of disparities which affects the perception and understanding of the concept. Another antecedent to the conceptual confusion lies in the difficulty of clarity on TgQ, with perplexity concerning what the term means, how it functions, and with this, a consequent associated plethora of notions. It is further intensified by Wang et al.'s (2011) 's argument of the presence of contradictory empirical evidence for the varied proposed conceptions of TgQ.

It has also been observed that regardless of the distinctive elements of the two concepts, the concepts also have established linking relationships. With a focus on the relationships, one may lose focus of their differing nature and associate the concepts with each other, with the tendency to use them interchangeably. Furthermore, a reason given for difficulty in defining TrQ has been identified to be concerned with differences in criteria used by scholars, or from a point to another, in defining TrQ (Mitchell et al., 2001). Cheng (2017) has similar sentiments about TgQ in his emphasis on its definition stemming from a load of varied stakeholders, with differing standpoints. More so, Henard (2010) adds that institutions also sometimes define quality (concerning TgQ) per their own terms. Mitchell et al. (2001) also further talked about the idea of TrQ, being an idea that changes with time, with empirical evidence of the historical shift in beliefs and interests as motivational sources.

\section{Conceptual Analysis}

It is about time a Conceptual Analysis (CA) for TgQ and TrQ was carried out. CA covers the representation of distinction between terms and an analysis of their meanings (Myburgh \& Tammaro, 2013), and the process is expedited in itself by the concepts, as put this way by the authors, "Concepts themselves create a framework for understanding." Furthermore, this understanding enables analysis of the relationships between concepts (Tahtinen \& Havila, 2019), which are crucial elements in this paper. Therefore, following the direction of these authors, CA in the context of this study entails representing the distinction between $\mathrm{TgQ}$ and $\mathrm{TrQ}$, analyzing their definitions, pursuing an understanding of the concepts, and using these elements to illustrate the relationships between the concepts.

In practice, (CA) deals with defining terms and examining their understanding (Myburgh \& Tammaro, 2013). Then the authors, in defining a concept, referred to it as a phenomenon, which suggests the role it plays in connection to other concepts. Relating to $\operatorname{TgQ}$ and $\operatorname{TrQ}$, we are guided by the authors on how to distinguish between the terms and attain comprehension of the concepts, which is aided by identifying the role of each concept on the other. Thus, the series of ideas offered by the authors, with the classification done, form the basis for analysis and distinction. Additionally, according to Tahtinen \& Havila (2019), the comprehension of concepts would have to precede the possibility of discussion concerning the relationships between concepts. Furthermore, with this as a springboard, our CA procedure involved classification, which aided in breaking down the concepts per their definition, dimensions, components, and predictors.

It also aided the further examination of the concepts, in line with the conceptual analysis approach- an analytical reflection on a myriad of descriptions and interpretations of concepts referent to a common idea. It is instrumental in the unraveling of Conceptual Confusion (CC) and expounding the numerous terms and concepts, while admitting to meanings being different and susceptible to change with time, context, among others (Tahtinen \& Havila, 2019). Stemming from these ideas, this study exposed meanings, illustrated boundaries of the concepts, elucidated dimensions of the focal concept, unraveled by some attached meanings in existing research. Finally, we reviewed some of the many definitions of the two concepts and their use in literature, as Evan's (2002) study found that: 
Defining, or at the very least, formulating clear interpretations of, key concepts is an essential feature of all study since it allows conceptual parameters, dimensions, constituents, and features to be identified, which, in turn, facilitates recognition of what does and does not constitute, and, therefore, represent, the concept(s) being studied. Moreover, the conceptual distinction of this kind is essential to examining and understanding processes and influences, which, by providing the key to formulating implications for policy and practice, constitute the rationale for the study. (pp. 127128).

Thellefsen (2004) further clarified that classification of a concept by its components, dimensions, among others (as this paper does), tends to accelerate future relational research. Table 1 shows how different authors perceive the terms, allowing us to see their orientation toward these concepts. Table 1 also doubles up as proof of the CC existing between TgQ and TrQ, and from Table 1, it is evident how the descriptions of TgQ and TrQ are similar, with only a few opposing perceptions.

\section{Classification of Constituents and Use}

One of the uses of classification is to separate and compare patterns of usage. It also helps prove the existence of differences in concepts if existing and may even aid with explanatory purposes to transform definitions needed to understand the concepts' role (Myburgh \& Tammaro, 2013). Classification also assists in unveiling existing relations between concepts or entities, and discovery of relations between entities assist in their understanding, then the relationships also give away their roles on each other and their general purpose. More so, the relations open a path for evolution and expansion. Hence, the ability to connect, explain, contribute to understanding, and then development begins with the analysis: putting apart, so they can come together.

For these reasons, the various $\operatorname{TgQ}$ and $\operatorname{TrQ}$ inputs, meanings, and descriptions found in some literature are presented and classified into their respective associative categories. The classification involved highlighting the referenced inputs to the concepts identified, then coding, grouping, and analyzing these constituent parts of the concepts-the organization and classification aid in giving a coherent view of usage.

Table 2. Classification of Teaching Quality and Teacher Quality

\begin{tabular}{|c|c|c|c|c|c|c|c|c|}
\hline Constituents & 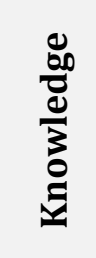 & 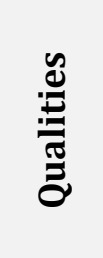 & 莞 & 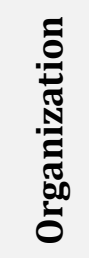 & 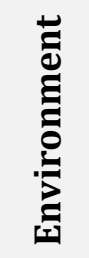 & 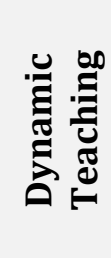 & 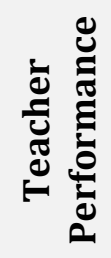 & ڤัă \\
\hline Beliefs & TgQ & & & & & & & \\
\hline Attitudes & & $\operatorname{TgQ}$ & & & & & & \\
\hline Knowledge & $\operatorname{TgQ}$ & & & & & & & \\
\hline Disposition & & $\operatorname{TgQ}$ & & & & & & \\
\hline Teacher performance & & & & & & & $\operatorname{TgQ}$ & \\
\hline Conducive classroom climate & & & & & TgQ & & & \\
\hline Class management/ organization & & & & TgQ & & & & \\
\hline Adaptive teaching & & & & & & $\operatorname{TgQ}$ & & \\
\hline Support for students & & & & & & & & $\operatorname{TgQ}$ \\
\hline Cognitive activation & & & & & & $\operatorname{TgQ}$ & & \\
\hline Teacher intellect & $\operatorname{TgQ}$ & & & & & & & \\
\hline Teacher result & & & & & & & $\operatorname{TgQ}$ & \\
\hline Cognitive resources & $\operatorname{TgQ}$ & & & & & & & \\
\hline Teacher actions & & & & & & & & $\operatorname{TgQ}$ \\
\hline Role of the classroom & & & & TgQ & & & & \\
\hline Pedagogical style \& approach & & & & & & & & $\operatorname{TgQ}$ \\
\hline
\end{tabular}




\begin{tabular}{|c|c|c|c|c|c|c|c|c|c|c|}
\hline Constituents & 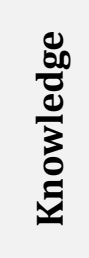 & 兽 & & 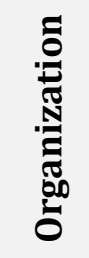 & 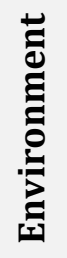 & 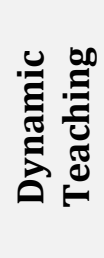 & 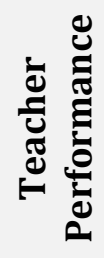 & 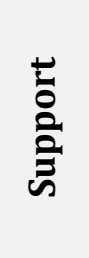 & 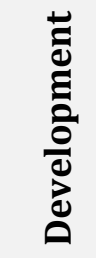 & 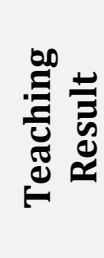 \\
\hline Student-teacher relationship & & & & & & & & TgQ & & \\
\hline Student engagement & & & & & & & & $\operatorname{TgQ}$ & & \\
\hline Student achievement & & & & & & & & & & $\operatorname{TgQ}$ \\
\hline Teacher behaviors & & & & & & & & TgQ & & \\
\hline Teacher activities & & & & & & & & TgQ & & \\
\hline Adaptive developmental & & & & & & & & & & \\
\hline Regulation & & & & & & & & & TgQ & \\
\hline Teacher/professional knowledge & TrQ & & & & & & & & & \\
\hline Teacher/professional preparation & & & TrQ & & & & & & & \\
\hline Professional qualification & & & TrQ & & & & & & & \\
\hline Disposition & & TrQ & & & & & & & & \\
\hline Teacher effectiveness level & & & & & & & $\operatorname{TrQ}$ & & & \\
\hline Abilities & TrQ & & & & & & & & & \\
\hline Skills & & $\operatorname{TrQ}$ & & & & & & & & \\
\hline Attributes & & $\operatorname{TrQ}$ & & & & & & & & \\
\hline Personal development & & & & & & & & & TrQ & \\
\hline Professional development & & & & & & & & & TrQ & \\
\hline Experience & & & $\operatorname{TrQ}$ & & & & & & & \\
\hline Psychological characteristics & TrQ & & & & & & & & & \\
\hline Internal attributes & & $\operatorname{TrQ}$ & & & & & & & & \\
\hline Intellectual capabilities & TrQ & & & & & & & & & \\
\hline Traits & & $\operatorname{TrQ}$ & & & & & & & & \\
\hline Licensure & & & TrQ & & & & & & & \\
\hline Certification & & & $\operatorname{TrQ}$ & & & & & & & \\
\hline Teacher practices & & & & & & & & TrQ & & \\
\hline Teacher-student relationship & & & & & & & & TrQ & & \\
\hline Role of classroom & & & & $\operatorname{TrQ}$ & & & & & & \\
\hline Student achievement & & & & & & & & & & TrQ \\
\hline Instructional activities & & & & & & & & TrQ & & \\
\hline
\end{tabular}

Looking at some literature, $\operatorname{TgQ}$ and $\operatorname{TrQ}$ constituents came under a subcategory that assisted in the labeling and grouping for comprehension and analysis. The scope of the categories are as follows, knowledge: intellectual resources or mental positions; Qualities: the traits and characteristics; Qualification: conditions fulfillment in the profession; Organization: planning, arrangement, coordination, and structuring; Environment: affecting conditions; Dynamic Teaching: stimulative, and progressive teaching; Teacher Performance: teachers' accomplishing efforts; Support: intentional actions carried out or fostered by a teacher to assist students; Development: progress seeking endeavors; and Teaching Result: product of performance. We perceive from the classification that TgQ concerning the relationship between the concepts and the categories makes use of organization, environment, and dynamism in teaching, with the TrQ index: knowledge, qualities, qualification, development, purposed to lead to performance, support, and result- for the benefit of learners. The categorization effectively revealed some differences, relationships, and associated roles and has been helpful for comprehension, distinction, and clarity purposes in the following sections of the paper.

\section{Contention (Insight) Toward Understanding: Differences in How the Concepts are Understood}

Some of the contention on perceptions of the concepts are based on: the association of one concept's description with the other (Darling-Hammond et al., 2017; Fitchett \& Heafner, 2018; $\underline{\text { Mitchell }}$ 
et al., 2001; Wang et al., 2011); whereas others are related to disagreement on the inappropriateness of some related measurement frames, (Ferguson, 2012; Gitomer \& Zisk, 2015; Madu \& Kuei, 1993; Perez, 2013); as well as erroneous criteria for, and links to the concepts, ; (Baier et al., 2018; Cochran-Smith \& Fries, 2005; Kennedy, 2010; Mitchell et al., 2001; Rimm-Kaufman \& Hamre, 2010); and also limitation in definition, (Darling-Hammond, 2000; Perez, 2013; Rimm-Kaufman \& Hamre, 2010). For example, Rimm-Kaufman \& Hamre (2010) focused the concept of TrQ on teacher-student interactions; and equated TrQ to an automated relational output of student achievement. However, their former assumption is rejected by Kennedy (2010) on the reasoning that situational factors should take more precedence; and the latter by Mitchell et al. (2001) because the use of student achievement as an index of TrQ serves as a restrictive measure. See details in Table 3.

Table 3. Contests in Scholars' Understanding of Concepts

\begin{tabular}{|c|c|c|c|}
\hline Position & Author & Contention & Author \\
\hline $\begin{array}{l}\text { Teaching quality } \\
\text { connoting } \\
\text { professional } \\
\text { ability to teach }\end{array}$ & $\begin{array}{l}\text { Darling-Hammond et al. } \\
\text { (2017) }\end{array}$ & $\begin{array}{l}\text { Professionalism to } \\
\text { teach: Teacher Quality }\end{array}$ & $\begin{array}{l}\text { Fitchett and Heafner } \\
\text { (2018) }\end{array}$ \\
\hline $\begin{array}{l}\text { Teaching quality } \\
\text { as including } \\
\text { cognitive aspects } \\
\text { like knowledge } \\
\text { and dispositions of } \\
\text { teacher }\end{array}$ & Wang et al. (2011) & $\begin{array}{l}\text { Knowledge and } \\
\text { disposition of teacher- } \\
\text { embodied in the } \\
\text { definition of teacher } \\
\text { quality instead }\end{array}$ & Mitchell et al. (2001) \\
\hline $\begin{array}{l}\text { Student perception } \\
\text { for evaluation of } \\
\text { teaching quality }\end{array}$ & Ferguson (2012) & $\begin{array}{l}\text { The use of student } \\
\text { evaluation as a teacher } \\
\text { performance indicator } \\
\text { impacts negatively on } \\
\text { teaching quality }\end{array}$ & Madu and Kuei (1993) \\
\hline $\begin{array}{l}\text { Teacher } \\
\text { knowledge used as } \\
\text { a measurement of } \\
\text { teaching quality }\end{array}$ & Gitomer and Zisk (2015) & $\begin{array}{l}\text { This results in the } \\
\text { downgrade of the } \\
\text { weight or possible } \\
\text { value of teaching } \\
\text { quality }\end{array}$ & Perez (2013) \\
\hline $\begin{array}{l}\text { Ascribing teacher's } \\
\text { personal qualities } \\
\text { to teaching quality }\end{array}$ & $\begin{array}{l}\text { Cochran-Smith and Fries } \\
\text { (2005); Baier et al. (2018) }\end{array}$ & $\begin{array}{l}\text { Exaggeration in the } \\
\text { ascription of the } \\
\text { teacher's personal } \\
\text { qualities to teaching } \\
\text { quality }\end{array}$ & Kennedy (2010) \\
\hline $\begin{array}{l}\text { Teacher's personal } \\
\text { characteristics' } \\
\text { influence on } \\
\text { teacher's behavior }\end{array}$ & $\begin{array}{l}\text { Rimm-Kaufman } \\
\text { Hamre (2010) }\end{array}$ & $\begin{array}{l}\text { Fundamental } \\
\text { attribution error and } \\
\text { overstatement of the } \\
\text { impact of personal } \\
\text { characteristics on } \\
\text { teachers' behavior }\end{array}$ & Kennedy (2010) \\
\hline $\begin{array}{l}\text { Student } \\
\text { achievement as an } \\
\text { indicator of } \\
\text { teacher quality }\end{array}$ & $\begin{array}{l}\text { Rimm-Kaufman and } \\
\text { Hamre (2010) }\end{array}$ & $\begin{array}{l}\text { Represents a narrow } \\
\text { gauge }\end{array}$ & Mitchell et al. (2001) \\
\hline
\end{tabular}




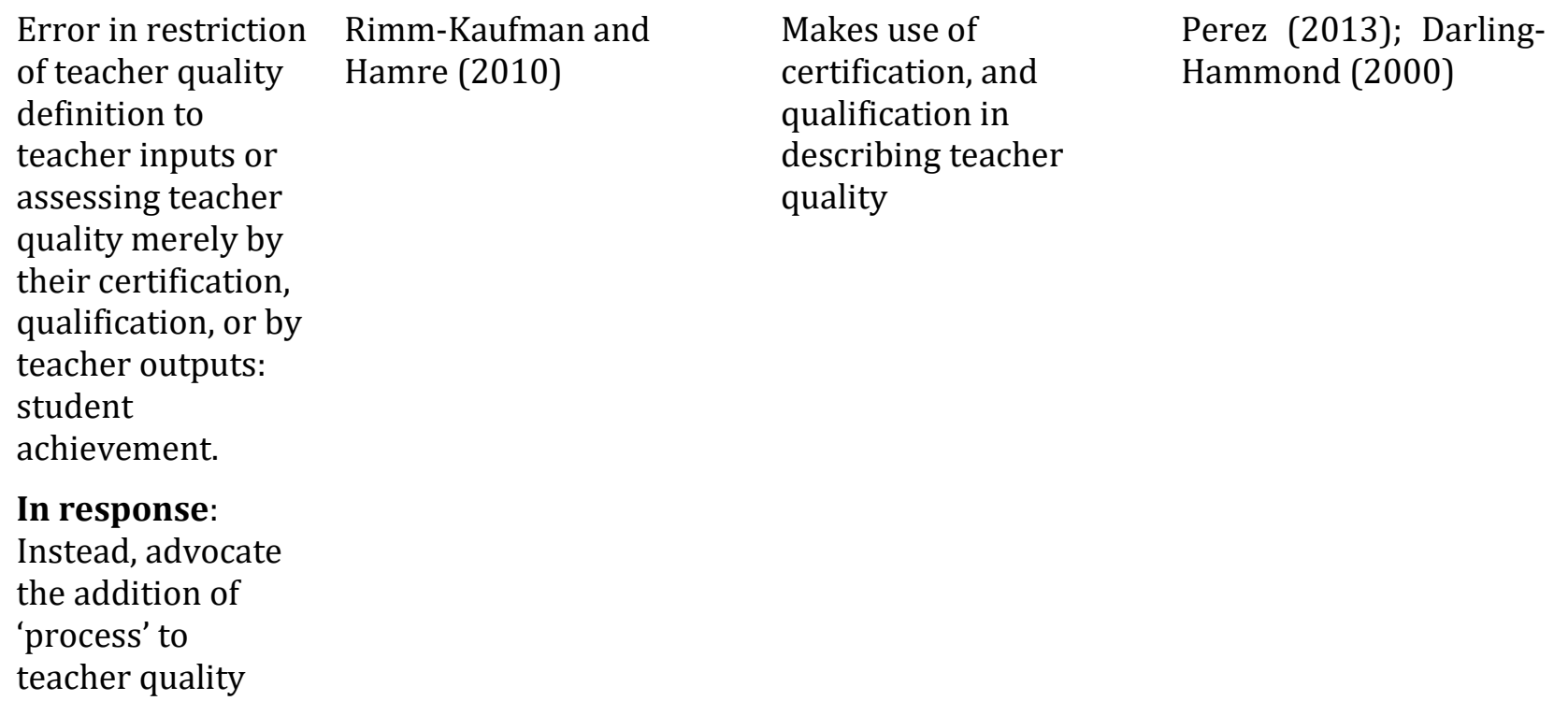

\section{Distinguishing Between Teaching Quality and Teacher Quality}

Table 4 serves as emphasized evidence that differences do exist between the two concepts in content and realization and likewise justifies the need for distinction. There is a general helpful instituted notion of diversity put forward in authors' conceptualization of the concepts, like the mention of the concepts having a meeting point (Darling-Hammond et al., 2017; Rimm-Kaufman \& Hamre, 2010), proving points of separation before or after the mentioned meeting points. In distinguishing between the two concepts, we found a layered trail of hints left behind by scholars in their discourse on the subjects, which was beneficial for assisting in comprehension, distinction, and relationship establishment.

On some occasions, without their explicit awareness per se, some authors' works and their discussions on the concepts endorsed existent distinctions between $\operatorname{TgQ}$ and TrQ; assisted in uncovering distinction indicators; cleared the way for resolution of the built-up confusion; and allowed access to an essential part of our work- how the authors subconsciously perceive these concepts and how it directs them, as compared to what they say about the concepts. Then, of course, our understanding and reflection also come through to enlighten the concepts.

Table 4. Distinction between Teacher Quality and Teaching Quality (Proof of Differentials)

\begin{tabular}{lc}
\hline \multicolumn{1}{c}{ Distinction } & \multicolumn{1}{c}{ Author } \\
\hline $\begin{array}{l}\text { Teaching quality occurs with the presence of } \\
\text { learners, while teacher quality is possessed with } \\
\text { or without the introduction of learners }{ }^{* 1}\end{array}$ & Kaplan and Owings (2001)
\end{tabular}

Teaching quality- teacher actions in the Perez (2013) classroom (what teachers do in the classroom), teacher quality- what teachers bring to the classroom (what the teacher knows)/ what the teacher uses in the classroom-teaching quality, versus what the teacher brings to the classroomteacher knowledge

Teaching quality- its elements are higher indicators of/ and possess higher chances for Perez (2013) teacher effectiveness, teacher quality elements possess somewhat low chances or indicators for teacher effectiveness 
Promotion of one (teacher quality) enhances the promotion of the other (teaching quality)

Examination of the intersection between teacher quality and teaching quality -the study of the meeting point: suggestive of their possession of divergent points

Teacher quality connotes personal ability while teaching quality has to do with the professional ability

The complementary role of teacher quality on teaching quality

Questioning the existence of an excellent approach to high teaching quality, if psychological and developmental processes are instrumental factors to teacher quality?

Identification of the role of each concept on the other

Terming teacher quality as the skills and attributes related to teaching quality

Understanding teacher quality by determining the constituents of high teaching quality helps to understand teacher quality and to improve it
Hiebert and Stigler (2017)

Fitchett and Heafner (2018)

Darling-Hammond et al. (2017)

Sachs (2016)

Rimm-Kaufman and Hamre (2010)

Myburgh and Tammaro (2013)

Churchward and Willis (2018)

Rimm-Kaufman and Hamre (2010)

\begin{tabular}{ll}
\hline \multicolumn{1}{c}{ Distinction (Authors' Conceptualized Logic) } & \multicolumn{1}{c}{ Influencing Authors } \\
\hline $\begin{array}{l}\text { Consideration of teaching quality as an act of } \\
\text { measurement, and teacher quality as a } \\
\text { modifying description }\end{array}$ & Influenced by Perez (2013) \\
$\begin{array}{l}\text { Role of the concepts in theory: fulfillment of the } \\
\text { aim(s) of the concepts }\end{array}$ & Influenced by (Perez 2013) \\
$\begin{array}{l}\text { The motive of action (teaching quality) versus } \\
\text { personality (teacher quality) }\end{array}$ & Authors' perception \\
$\begin{array}{l}\text { Practice (teaching quality) versus theory } \\
\text { teacher quality) }\end{array}$ & Authors' perception \\
$\begin{array}{l}\text { Application (teaching quality) versus knowledge } \\
\text { teacher quality) }\end{array}$ & Authors' perception \\
$\begin{array}{l}\text { Output/gains (teaching quality) versus } \\
\text { input/investment (teacher quality) }\end{array}$ & Influenced by Kaplan and Owings (2001) \\
\hline
\end{tabular}

Note. ${ }^{* 1}$ Though it ought to be acknowledged that the presence of learners would serve as catalysts in sharpening purposes of both concepts, especially teaching quality.

The determination of a description as $\operatorname{TgQ}$ or TrQ ought to, as a part of the guide toward clarity, consider the factors outlined hence. Furthermore, the authors need to ascertain these in comparison with motives. Distinctive indicators observed are summarized in Figure 1. 


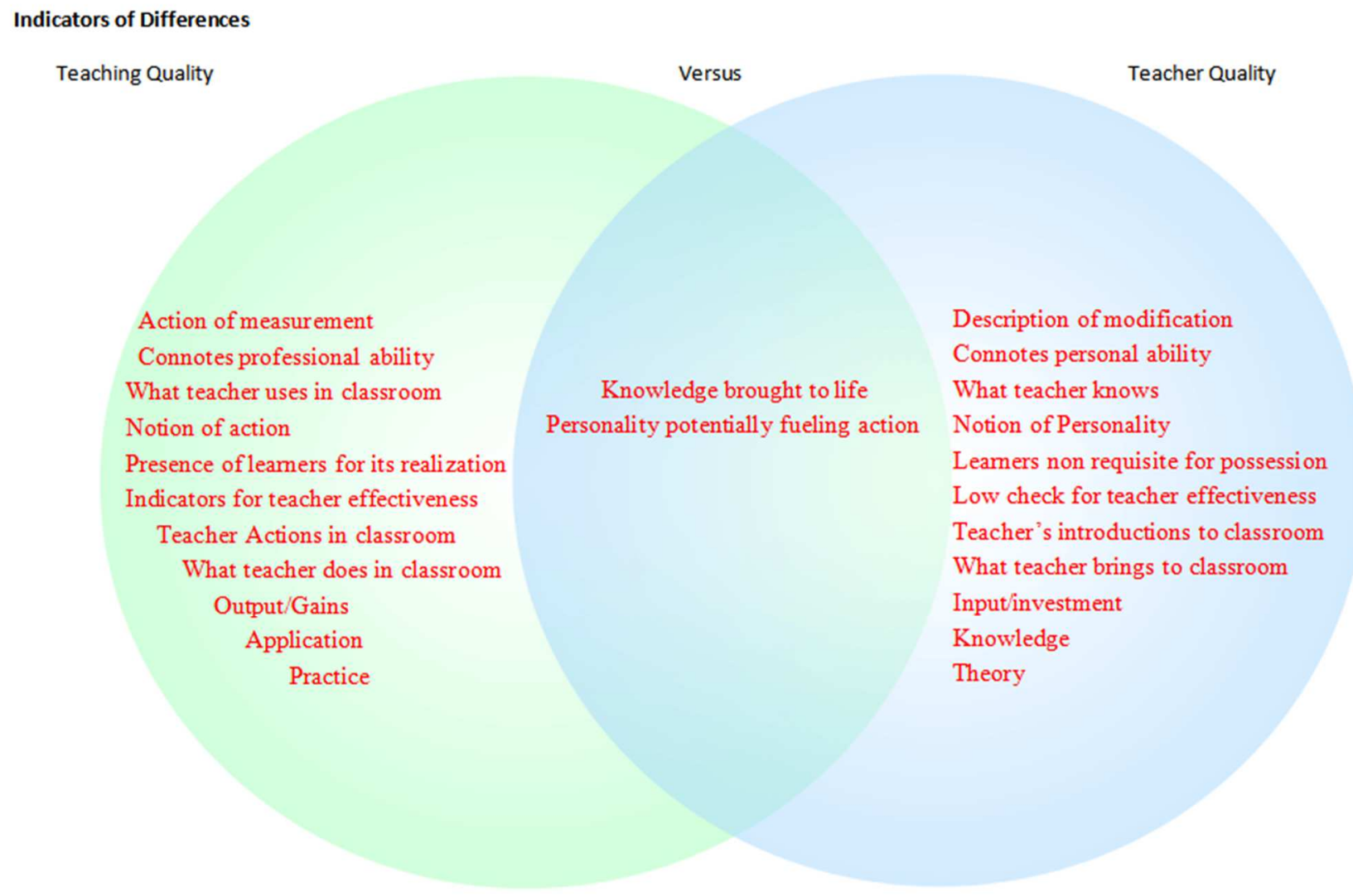

Figure 1. Differentiation model

\section{Reflections on the Distinctions}

With TrQ, there seems to be an associated concern with the requisite intellectual, professional, and experiential skills and attributes of a teacher. At the same time, $\operatorname{TgQ}$ would represent the application of these requisite high-quality skills in teaching (the methodology and actual practice of teaching). The 'applicability' of requisite knowledge seems to be the critical component of the concept of 'teaching' quality and its primary distinguishing feature. The relation between $\operatorname{TrQ}$ and $\operatorname{TgQ}$ is suggested to be more than an inter-relational link, on the basis that it should be hard to ascribe a quality to a teacher if he/she fails in the fundamental task of a teacher- teaching. On this ground, TrQ should have a bearing on $\mathrm{TgQ}$ and vice versa. We believe it is in this vein that a supporting position is shown in the mention of TgQ as a measure of TrQ, (Mitchell et al., 2001), reiterating the position of Sachs (2016)- the complementary role of $\mathrm{TrQ}$ on $\mathrm{TgQ}$, but in a converse manner, it seems.

\section{Use of the Relationships as Additional Terminologies' Differentiators}

It has been clear that a model should be developed to explain the concepts and how they function, and their relationship with each other. As a result, their principles and purpose toward each other would be unveiled to differentiate them, due to the fact that relationships between concepts are the propositions or principles that when put forward in statements articulate those relationships, (Myburgh \& Tammaro, 2013). 
$\operatorname{TgQ}$

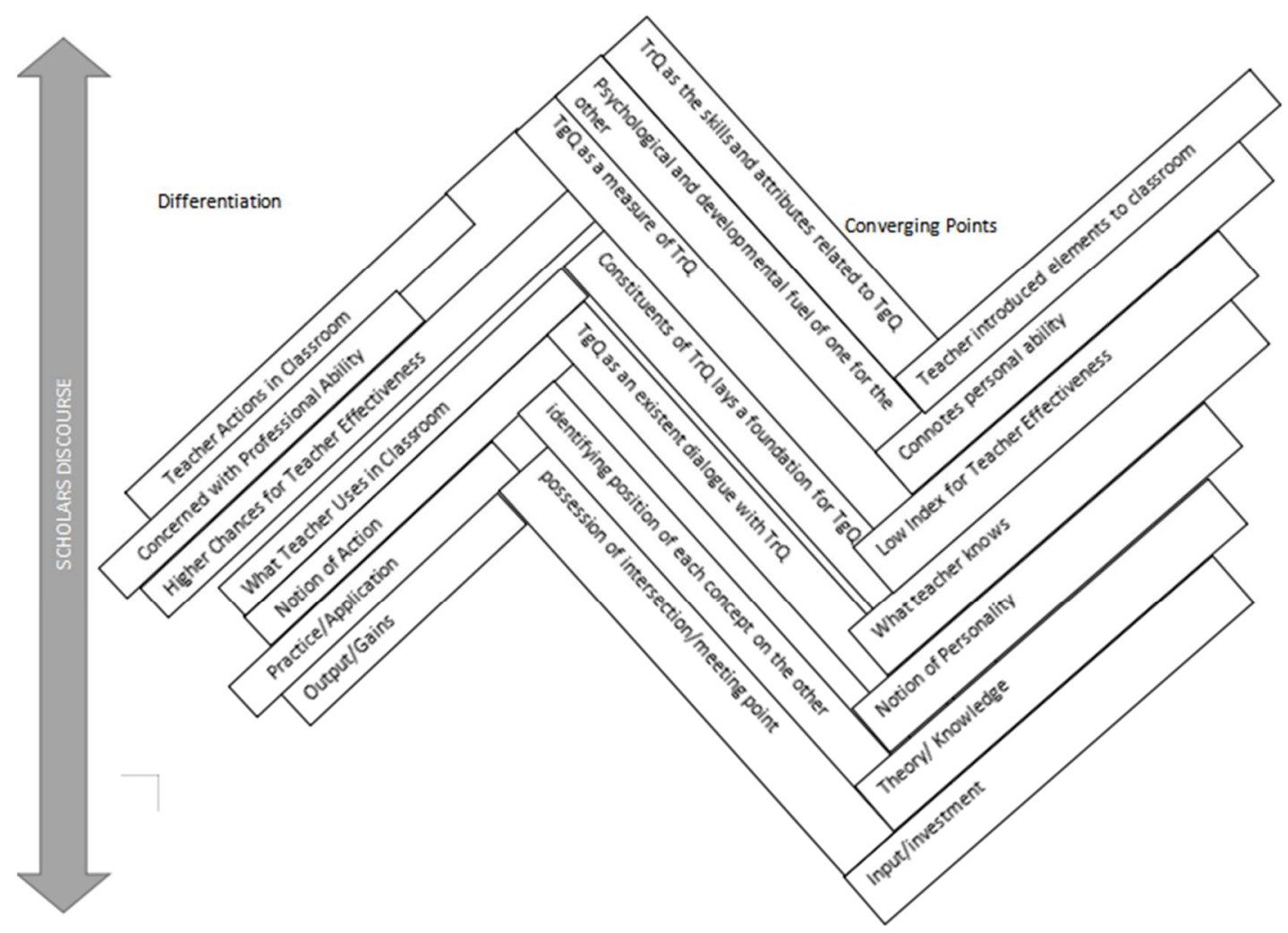

Tra

Differentiation

Figure 2. Relational-differentiation model

Hence, Figure 2 gives a visual representation of how $\operatorname{TgQ}$ is related to $\operatorname{TrQ}$ (linking relationships) but at the same time is different from TrQ. The difference and corresponding relations can be found here by taking a position on $\operatorname{TgQ}$ and following it to its corresponding position on $\operatorname{TrQ}$ and their corresponding position with relationships- to find the linking relationship outlined. For instance, the first is TgQ: Teacher actions in the classroom/ as against/ TrQ: Teacher introduced elements to the classroom; with the connection of (relationship): TrQ as the skills and attributes related to TgQ (the linking relationship). A comparison of $\operatorname{TgQ}$, and $\operatorname{TrQ}$, where each concept is seen relative to the other.

\section{Other Purposes of the Relationships Between Teaching Quality and Teacher Quality}

The relationships found between the concepts can mainly be categorized into two: linking relationships (relationships of attachment) and distinctive relationships (relationships of detachment). These relationships were identified with the help of the classification, and differences that were uncovered between the concepts.

The relationships have been separated in Figure 3, with deriving roles (one of the purposes of the relationships), to show the diverse purposes. The distinctive relationships separate the concepts, placing them apart without a middle ground, whereas showing their relation simultaneously. Then the linking relationships prove a link between the concepts, a meeting point, and the connectedness to each other in highlighting their relationship to each other. Details are found in Figure 3. 


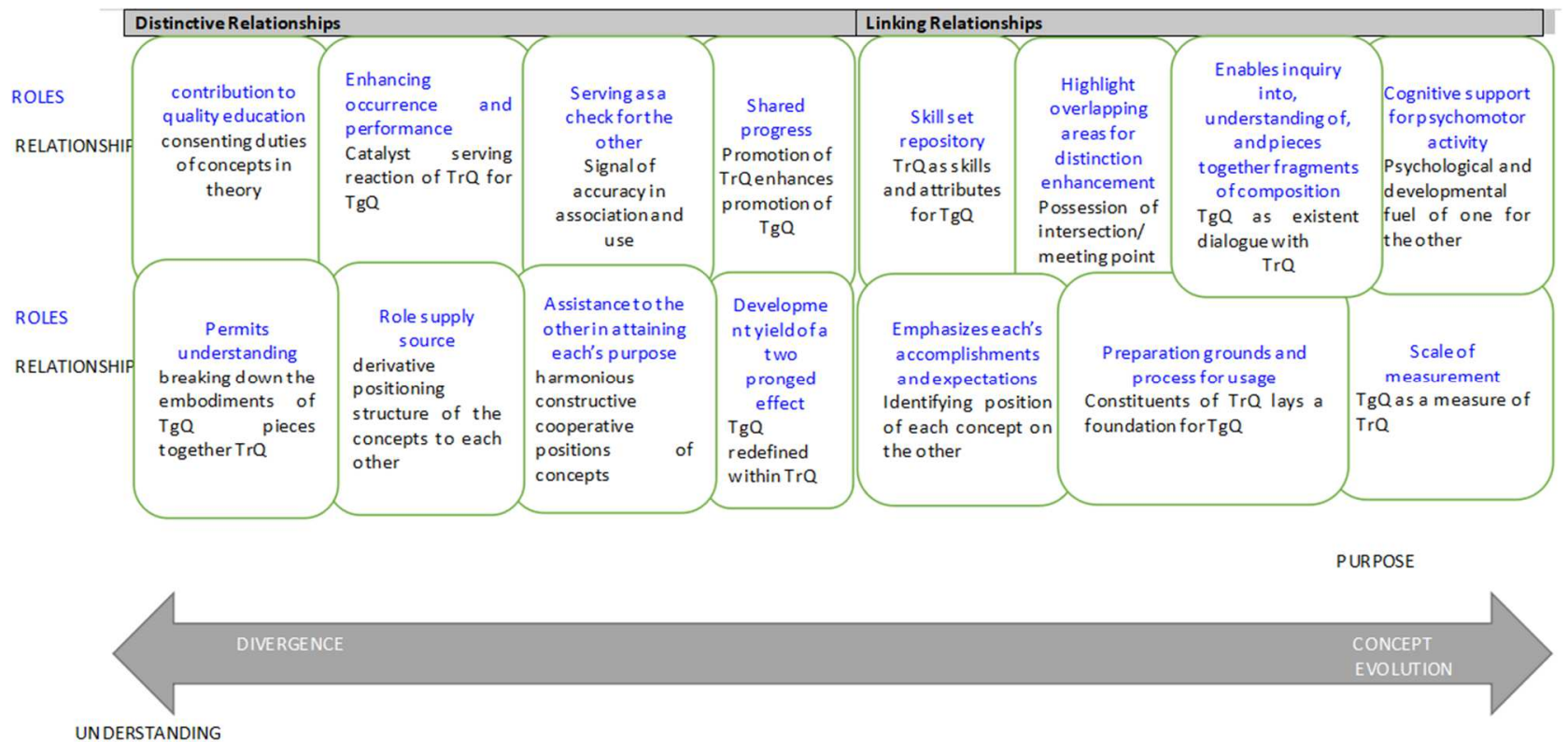

Figure 3. Depiction of the various relationship categories and their subsets

The contribution to the relationships (emphasized differences), and corresponding roles identification are outlined below: possession of intersection/meeting point, and divergent points, (Fitchett \& Heafner, 2018); complementary relationship-complementary role of TrQ on TgQ, (Sachs, 2016); question of path to TgQ with psychological and developmental processes fueling TrQ, (RimmKaufman \& Hamre, 2010); identifying role of each concept on the other, (Myburgh \& Tammaro, 2013); TgQ as an existent dialogue with TrQ, (Perez, 2013); TgQ as a measure of TrQ, (Mitchell et al., 2001); TrQ as the skills and attributes related to TgQ, (Churchward \& Willis, 2018); consenting duties of concepts in theory, (Perez, 2013); catalyst serving reaction of TrQ, for TgQ, (Hiebert \& Stigler, 2017);

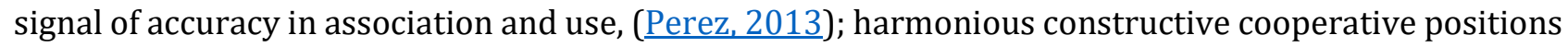
of concepts, (Fitchett \& Heafner, 2018); derivative positioning structure of the concepts to each otherTrQ to be a subdivision of TgQ, (Churchward \& Willis, 2018); breaking down the embodiments of TgQ assisting to piece together/allowing understanding of the concept of TrQ (constituents of TrQ have an intertwining relationship in laying a foundation for TgQ), (Rimm-Kaufman \& Hamre, 2010); TgQ redefined within TrQ, (Rimm-Kaufman \& Hamre, 2010); and joint progress relationship- promotion of one: TrQ, enhances promotion of the other: TgQ, (Hiebert \& Stigler, 2017; Rimm-Kaufman \& Hamre, 2010). These relationships also stand to highlight the roles of the concepts in theory and toward each other.

\section{Way Forward}

Although methods to deconstruct concepts (Tahtinen \& Havila, 2019) are available, we failed to find an appropriate approach to eliminate CC and allow the chance for conceptual development sustainably. Thus, a strategic clarification framework was designed, birthed from the research questions. Myburgh \& Tammaro (2013) offered that concepts in themselves offer frameworks for understanding, for meaning to be attained by expressing them according to their properties and the connections between them. Making meaning of this, we utilized the classification in creating a framework for comprehension and distinction toward confusion omission. 


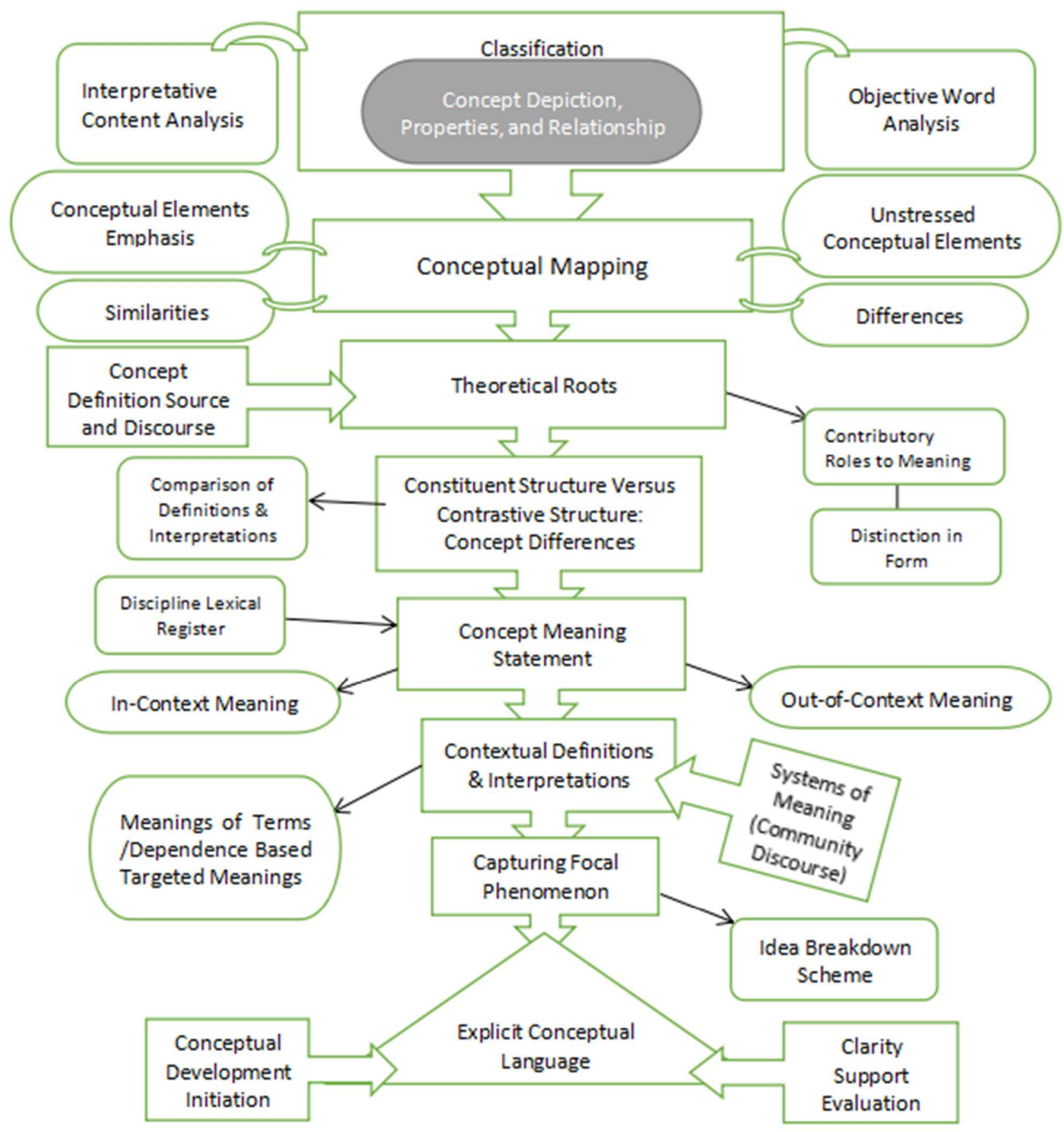

Figure 4. Strategic clarification framework

The Strategic Clarification Framework (Figure 4) is for concept distinction and clarification. It shows the tasks and logic of the process toward clarity and distinction. It emphasizes the complexity of the phenomenon and embodies the path to tackling the conceptual confusion, opening up avenues for clarity in response to the research questions. The framework also offers amplification of interrelating entities in the field and offers a way forward for reconceptualizing the terms under study here. To the best of our knowledge, this is the first attempt to create a framework that attempts to clear the conceptual confusion of $\mathrm{TgQ}$, and $\mathrm{TrQ}$, and one of few directed at conceptual clarity in general.

\section{Procedure for Distinction and Clarity}

In pursuit of the concepts' differentiation and clarity, the strategic clarification framework (See Figure 4) incorporates the major tasks involved in comprehension, differentiation, and clarification of 
concepts as advocated in this paper. In addition, it has levels of interactive processes, and the discourse that takes place in the framework is described as follows:

1. Classification of concept features and characteristics to provide a coherent view either by

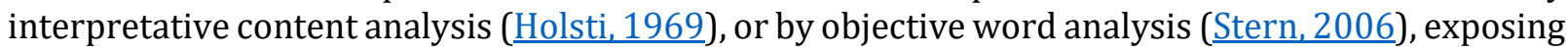
concepts' depiction- properties, and relationships (unveiling their roles also), (Tahtinen \& Havila, 2019).

2. Conceptual mapping/map: chart depicting the different parts of the units that make up the concept. This process and eventual product would assist in uncovering similarities and differences among the concepts.

3. Stating theoretical roots and authors of the concept (if they exist) is a source of conceptual inspiration: whether from different disciplines, et cetera. Followed by reasons for the crossdisciplinary conceptual adoption, if applicable, and its purpose- fit with its current need. Thus, the conceptual maps would depict the theoretical roots of the concepts and emphasize their distinction in form and contributory roles to meaning (Tahtinen \& Havila, 2019).

4. Establishing Constituent structure Versus Contrastive structure: Concept differences establishment. Comparing concept definitions and interpretations for the establishment of the governing boundaries of the concept.

5. Conceptual Meaning Statement: the logical meaning founded on the form of the word stated for enhanced elucidation. Done with the additional help of the vital discipline lexical register: to offer coherence in structure of meanings, describe ideas and their relationship with each other, and establish needed boundaries in an area of study (Myburgh \& Tammaro, 2013).

6. Contextual definitions and contextual interpretations- context features explanation. It speaks to the concepts contextualized. The strategic clarification framework gives voice to the context in guiding stakeholders to distinguish between the concepts at hand. Here, a specific milieu is to be clarified and exemplified, and audience; culture of thought; and circumstances, et cetera, catered for. To do this, one may need to determine systems of meanings within related community discourses; as Sartori (2009) rightly put it, concepts' content is derived from context and envisioned through their labels, without which discussions are impossible. Furthermore, context generally determines the meanings of terms (Thellefsen, 2004). Hence, this stage offers an opportunity for cultural custodians to review and locate for themselves space within which to assert their meaning amid the multiple viewpoints imposed on them.

7. Capturing the core of the focal phenomenon: For this part, concepts require a thorough depiction of reality: a -thought-break-down- scheme, serving to assist one's audience stay in the same wavelength with the author and the larger literary community. The notion of intent in the use of a concept, for example, would then be clarified here. This position is supported by Tahtinen and Havila (2019) in their assertion that when explicit definitions are not offered, authors' messages and what readers may receive may not bear a resemblance.

8. Explicit conceptual language. This stage is characterized by evaluating the support offered for clarity (to check if it served its purpose), and conceptual development may be initiated from here. These elements occupy a critical position in the process of growth of concepts. 


\section{Theoretical Framework}

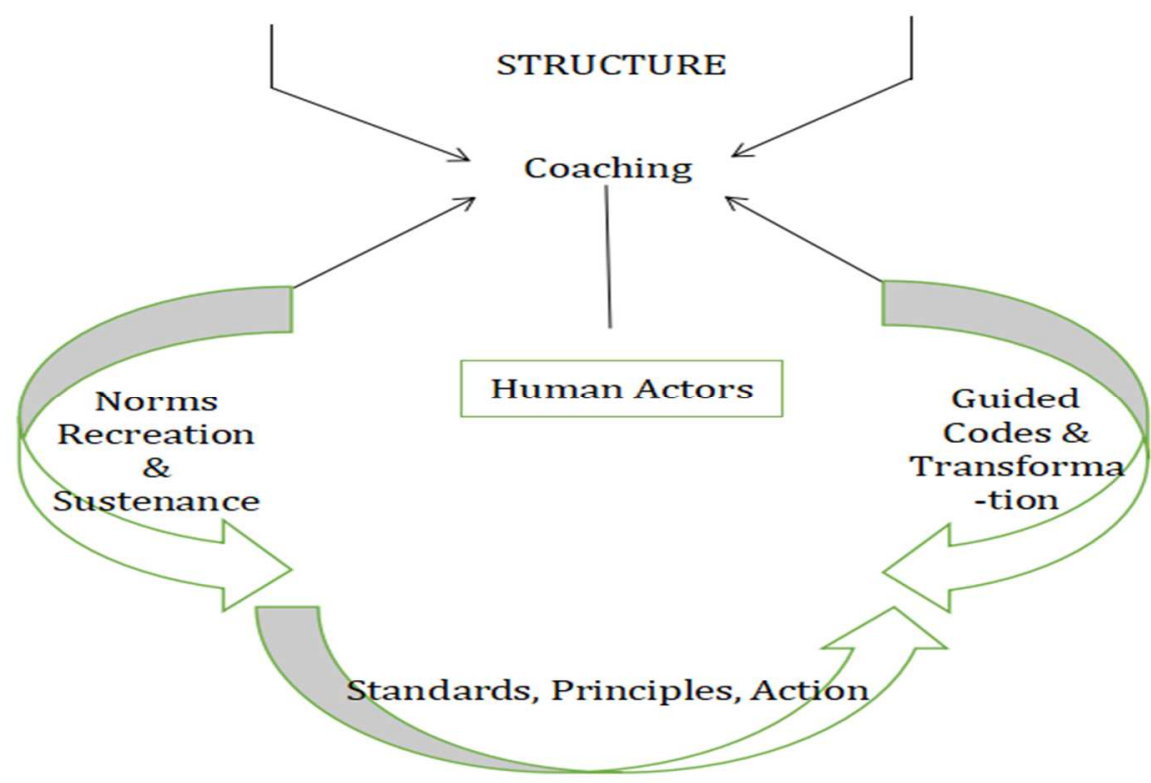

Figure 5. Giddens structuration theory

There seem to be no bounding scope of the terrain that TgQ covers, its range hence, is probably only limited by one's imagination. However, the proposed framework would assist in drawing the line and demarcate its boundaries. This article is the first to apply Gidden's structuration theory to foster clarity development amid conceptual confusion. Gidden's structuration theory maintains that human actors have an instrumental role in the recreation and sustenance of codes and norms in communities. In alignment with this, Giddens explicates the significance of the structure, which he insisted, coached agents who form a part of creating the structure in an unending cycle. Furthermore, by reforming guiding codes, the structure offers standards, principles and means, channels for action, and forms of praxis materialized by human actors. It is this enactment we are striving for here. An emphasis made on the qualities of structure, weighty in meaning for our work, is its two-pronged ability to constrain and enable. Giddens adds that structure is open to transformation, as it also serves as mediation, meaning its application to our concepts would still leave room for expansion, as it serves as a negotiation tool. He also professes that it has a regulator for time, which we view to be especially relevant to combat the change that visits concepts with time, contributing eventually to conceptual confusion. Also, human actors are confirmed by this theory to reify systems in communities, which they organize and develop. We offer this intervention of human actors in our proposal for confusion resolution in a collective human agency approach toward clarity between $\operatorname{TrQ}$ and TgQ.

There is an identified call for structuration: a need for collaboration of stakeholders to promote involved engagement and institutional norms, with their contribution of informed perspectives from the community standpoint, streamlined with set standards and transparency and openness of meanings and interpretations. Exemplifying intersubjectivity on a broader scale in aiming for a level of agreement (definition) of an idea with invested discourse is also targeted. These are also to be aimed at long-term community education in response to the pressing conceptual confusion. The requirement of conceptual responsibility in researchers' literary and debate approaches, borrowing from Giddens' idea of structuration theory, forms a solid human agency scaffolding to propel the clarity approach, with the establishment of institutional structures and insightful activities: hence, we propose the institutional system- for responsibility to lead the proposed activism.

\section{CONCLUSION}

It has been observed mainly that discussion concerning $\operatorname{TgQ}$ or $\operatorname{TrQ}$ tends to continually interchange the use of the concepts erroneously, perhaps by unconscious acknowledgment of the inter- 
connectedness of the concepts. As Gitomer (2018) put it, "Domain definitions vary in their specificity with tradeoffs in their range of applicability and specificity of inference," and people sometimes tend to fall on the concept of satisfaction with proximity to the target. However, the terms' relational effects': TrQ and TgQ, on each other, do not amount to an equation of the terms on the level of meaning or implication. Reviewing the constituents and interpretations of the terms has enabled the relationships between the concepts to surface. Their inter-relational positions, marking the distinctions of the two concepts and enhancing the understanding of their difference, are relevant to the establishment of our contribution to the literature. We also realized that exploring the relationships between the concepts helped establish more specific meanings from the general concepts. This new understanding offered assistance in clarification, serving two significant purposes: distinguishing the terminologies to allow for the ease of inter-and multidisciplinary work; and allowing the possibility of a model constructed on the principles offered, positioning the roles of the concepts.

This research has practical implications in its assistance provision for: education stakeholders to be guided in identifying professional development needs and being informed in appropriate support provision; clarifying areas for leadership coaching and mentoring of teachers to improve education; and providing awareness for teachers in their needs' improvement areas, giving them a chance for informed self-assessment and opening up the possibility for assistance receptivity. Then when these are made possible, teachers in our classrooms have the chance to develop meaningfully; school improvement is achieved (Mincu, 2015), and student achievement is attained (Hattie, 2009; Rice, 2003). The distinction of TrQ and TgQ additionally aids in practice: with placing TrQ and TgQ in the educational system context, to account for relevant school factors such as- student behavior, for research purposes; and is relevant in modeling relations between teacher quality, teaching quality, and student characteristics such asstudent outcomes, in cross- country subject analysis for example, (Nilsen \& Gustafsson, 2016).

A justification in the clear-cut demarcation of the two prominent terminologies in this paper is emphasized by Kaplan and Owings (2001) 's stand that the separation and use of TgQ and TrQ allow for clarity in discussion and plans for action. By knowing their scopes, and differing dimensions, stakeholders would be better informed in developing promotion strategies for their individual growth. Furthermore, the discourse of these two concepts and how they interrelate and shape classroom activity could also be accurately focused on enhancing performance. Hence, this study serves as an initiation of a much-needed discourse on the subject's intricacies and a required course of action.

In its advocacy for definition and conceptual clarity, this study is needed to satisfy the need for shared understanding. Dealing with this would have a ripple solution effect on related issues such as difficulty establishing parameters of the study field or the concepts in the field, difficulty identifying the constructs' process, and construct validity threat. TgQ and $\operatorname{TrQ}$, what they require, feed on, are motivated by, and the variables they would occur with to thrive, stand to be further exposed and understood with such study. Hence, there is a call for a cohort of critical researchers and analysts to focus on this study area. The development of such related literature would have valuable contributions for comprehension of the essence of focused attention on these concepts. Furthermore, the development of such literature would also provide information and ideas for improvement and extension of the discussion scope and performance of the field, theory development (Freidson, 1994), and provide the avenue for constructive deliberation on the future direction and capacity of these ideas.

The weight of this script lies in the foundation that, to plan effectively and adequately for progress and development in TgQ or TrQ, there is the need to set these terms apart from similar ideas they are associated with, consider them in connection with such similar concepts nonetheless: but in careful attempts to develop logical frames of action for their development. In sum, this study adds to the research on conceptual confusion/ analysis and highlights a pathway for disentanglement of the confusion. It also contributes to research knowledge on the distinction between $\operatorname{TgQ}$ and $\operatorname{TrQ}$, offers evidence of conceptual confusion in this area, and highlights the importance of distinction in terminology use and purpose in establishing clarity.

\section{Funding and Conflicts of Interest:}

The authors declare that there is no funding and conflicts of interest for this article. 


\section{REFERENCES}

Arnold, I. (2011). John Hattie: Visible learning- A synthesis of over 800 meta-analyses relating to achievement. International Review of Education, 57, 219-221. doi:10.1007/s11159-0119198-8

Baier, F., Decker, A.T., Voss, T., Kleickmann, T., Klusmann, U., \& Kunter, M. (2018). What makes a good teacher? The relative importance of mathematics teachers' cognitive ability, personality, knowledge, beliefs, and motivation for instructional quality. British Journal of Educational Psychology, 89(4), 767-786. doi:10.1111/bjep.12256

Bell, C. A., Gitomer, D. H., McCaffrey, D. F., Hamre, B. K., Pianta, R. C., \& Qi, Y. (2012). An argument approach to observation protocol validity. Educational Assessment, 17, 62-87.

doi:10.1080/10627197.2012.715014

Brophy, J. (1999). Toward a model of the value aspects of motivation in education: Developing appreciation. Educational Psychologist, 34, 75-85. doi.org/10.1207/s15326985ep3402 1

Cheng, M. (2017). Reclaiming quality in higher education: A human factor approach. Quality in Higher Education, 23, 153-167. doi.org/10.1080/13538322.2017.1358954

Churchward, P., \& Willis, J. (2018). The pursuit of teacher quality: Identifying some of the multiple discourses of quality that impact the work of teacher educators. Asia-Pacific Journal of Teacher Education, 1-14. doi:10.1080/1359866X.2018.1555792

Cochran-Smith, M., \& Fries, K. (2005). The AERA panel on research and teacher education: Context and goals. In M. Cochran-Smith, \& K. M. Zeichner, (Eds.), Studying teacher education: The report of the AERA panel on research and teacher education (pp. 37-68). Lawrence Erlbaum Associates Publishers.

Cornelius-White, J. (2007). Learner-centered teacher-student relationships in the classroom. Review of Educational Research, 77, 113-143. doi:10.3102/003465430298563

Darling-Hammond, L., Burns, D., Campbell, C., Goodwin, A. L., Hammerness, K., Low, E. L., ... \& Zeichner, K. (2017). Empowered Educators: How high-performing systems shape teaching quality around the world. John Wiley \& Sons.

Darling-Hammond, L. (2000). Teacher quality and student achievement: A review of state policy evidence. Educational Policy Analysis, 8(1), 1-44. doi.org/10.14507/epaa.v8n1.2000

Fenstermacher, G. D., \& Richardson, V. (2005). On making determinations of quality in teaching. Teachers College Record, 107, 186-213. doi:10.1111/j.1467-9620.2005.00462.x

Fischer, J., Praetorius, A. K., \& Klieme, E. (2019). The impact of linguistic similarity on cross-cultural comparability of students' perceptions of teaching quality. Educational Assessment, Evaluation, and Accountability, 31, 201-220. doi:10.1007/s11092-019-09295-7

Fitchett, P. G., \& Heafner, T. L. (2018). Teacher quality or quality teaching? Eighth-grade social studies teachers' professional characteristics and classroom instruction as predictors of U.S. history achievement. Research in Middle-Level Education, 41(9), 1-17. doi:10.1080/19404476.2018.1514826

Freidson, E. (1994). Professionalism Reborn; theory, prophecy, and policy. Blackwell Publishers.

Giddens, A. (2005). The constitution of society: Outline of the theory of structuration. Routledge.

Gitomer, D. H. (2018). Evaluating instructional quality. School Effectiveness and School Improvement, 30, 68-78. doi:10.1080/09243453.2018.1539016

Gitomer, D. H., \& Zisk, R. C. (2015). Knowing what teachers know. Review of Research in Education, 39(1), 1-53. doi:10.3102/0091732X14557001 
Grosse, C., Kluczniok, K., \& Rossbach, H. G. (2017). Instructional quality in school entrance phase and its influence on students' vocabulary development: Empirical findings from the German longitudinal study BiKS. Early Child Development and Care, 189(9), 1-14. doi:10.1080/03004430.2017.1398150

Hafen, C. A., Hamre, B. K., Allen, J. P., Bell, C. A., Gitomer, D. H., \& Pianta, R. C. (2014). Teaching through interactions in secondary school classrooms: Revisiting the factor structure and practical application of the classroom assessment scoring system-secondary. The Journal of Early Adolescence, 35, 651-680. doi:10.1177/0272431614537117

Hattie, J. (2009). Visible learning: a synthesis of over 800 meta-analyses relating to achievement. Abingdon, Routledge.

Hénard, F., \& Roseveare, D. (2012). Fostering quality teaching in higher education: Policies and practices. Paris: OECD.

Henard, F. (2010). Learning our lesson review of quality teaching in higher education. Paris: OECD. doi.org/10.1787/9789264079281

Hiebert, J., \& Stigler, J. W. (2017). Teaching versus teachers as a lever for change: Comparing a Japanese and a U.S. perspective on improving instruction. Educational Researcher, 46(4), 169176. doi.org/10.3102/0013189X17711899

Hill, H., Umland, K., Litke, E., \& Kapitula, L. R. (2012). Teacher quality and quality teaching: Examining the relationship of a teacher assessment to practice. American Journal of Education, 118(489519)

Holsti, O. R. (1969). Content Analysis for the Social Sciences and Humanities. Addison-Wesley Publication.

Holtsch, D., Hartig, J., \& Shavelson, R. (2018). Do practical and academic preparation paths lead to differential commercial teacher quality? Vocations and Learning, 12, 23-46. doi:10.1007/s12186-018-9208-0

Kaplan, L. S., \& Owings, W. A. (2001). Teacher quality and student achievement: Recommendations for principals. NASSP Bulletin, 85, 64-73.

Kennedy, M. M. (2010). Attribution error and the quest for teacher quality. Educational Researcher, 39(8), 591-598. doi:10.3102/0013189X10390804

Klieme, E., Pauli, C., \& Reusser, K. (2009). The Pythagoras study-investigating effects of teaching and learning in Swiss and German mathematics classrooms. In T. Janik, \& T. Seidel (Eds.), The power of video studies in investigating teaching and learning in the classroom (pp. 137-160). Waxmann.

Klieme, E., Schümer, G., \& Knoll, S. (2001). Mathematikunterricht der sekundarstufe: Aufgabenkultur und unterrichtsgestaltung im internationalen vergleich [mathematics instructionnat lower secondary level: task culture and quality of instruction]. In J. Baumert, \& E. Klieme (Eds.), TIMSS - Impulse für schule und unterricht: Forschungsbefunde, reforminitiativen, praxisberichte und video-dokumente (pp. 43-57). Bonn: Bundesministerium für Bildung und Forschung

Madu, C. N., \& Kuei, C. (1993). Dimension of quality teaching in higher institutions, total quality management. International Journal of Management in Education, 4, 325-338. doi.org/10.1080/09544129300000046

Mincu, M. (2015). Teacher quality and school improvement: what is the role of research? Oxford Review of Education. 41. 10.1080/03054985.2015.1023013.

Mitchell, K. J., Robinson, D. Z., Plake, B. S., Knowles, K. T. (2001). Testing Teacher Candidates: The Role of Licensure Tests in Improving Teacher Quality. National Academy Press.

doi.org/10.17226/10090. 
Monsegue-Bailey, P. (2018). Instructional quality and middle school student engagement, achievement, attendance, and gender [doctoral dissertation Walden University]. Walden Dissertations and Doctoral Studies. https://scholarworks.walden.edu/dissertations/5906

Murphy, C. A., \& Jensen, T. D. (2016). Faculty teaching development: Using the multidimensional matrix of teaching development to guide teaching improvement activities. Journal of Effective Teaching, 16, 61-75. https://files.eric.ed.gov/fulltext/EJ1117782.pdf

Murphy, P. K., \& Alexander, P. A. (2000). A motivated exploration of motivation terminology. Contemporary Educational Psychology, 25, 3-53. doi:10.1006/ceps.1999.1019

Myburgh, S., \& Tammaro, A. M. (2013). Constructing a theoretical framework. In S. Myburgh, \& A.M. Tammaro, Exploring education for digital librarians (pp.133-172). Chandos Publishing. doi:10.1016/b978-1-84334-659-3.50007-4

Nilsen, T., \& Gustafsson, J. (2016). Teacher Quality, Instructional Quality, and Student Outcomes. Springer International Publishing.

Pelletier, F. J. (1994). The principle of semantic compositionality. Topoi, 13(1), 11-24. doi:10.1007/bf00763644

Perez, B. (2013). Teacher quality and teaching quality of 7th-grade algebra I honor teachers [doctoral dissertation, Florida Atlantic University]. DataStream. https://fau.digital.flvc.org/islandora/object/fau\%3A4133/datastream/OBJ/download/Teac her quality and teaching quality of 7 th-grade Algebra 1 Honors teachers.pdf

Pianta, R. C., Hamre, B. K., \& Allen, J. P. (2012). Teacher-student relationships and engagement: Conceptualizing, measuring, and improving the capacity of classroom interactions. In S. L. Christenson, A. L. Reschly, \& C. Wylie (Eds.), Handbook of research on student engagement (pp. 365-386). Springer. doi.org/10.1007/978-1-4614-2018-7 17

Pianta, R. C., \& Hamre, B. K. (2009). Conceptualization, measurement, and improvement of classroom processes: Standardized observation can leverage capacity. Educational Researcher, 38, 109119. doi.org/10.3102/0013189X09332374

Rice, J. K. (2003). Teacher Quality: Understanding the Effectiveness of Teacher Attributes. Economic Policy Institute.

Rieser, S., Naumann, A., Decristan, J., Fauth, B., Klieme, E., \& Büttner, G. (2016). The connection between teaching and learning: Linking teaching quality and metacognitive strategy use in primary school. British Journal of Educational Psychology, 86, 526-545. doi:10.1111/bjep.12121

Rimm-Kaufman, S., \& Hamre, B. (2010). The role of psychological and developmental science in efforts to improve teacher quality. Teachers College Record, 112(12), 2988-3023.

https://www.researchgate.net/publication/281379023 The Role of Psychological and Dev elopmental Science in Efforts to Improve Teacher Quality

Rjosk, C., Richter, D., Hochweber, J., Lüdtke, O., Klieme, E., \& Stanat, P. (2014). Socioeconomic and language minority classroom composition and individual reading achievement: The mediating role of instructional quality. Learning and Instruction, 32, 63-72. doi:10.1016/j.learninstruc.2014.01.007

Roehrig, G. H., Michlin, M., Schmitt, L., MacNabb, C., \& Dubinsky, J. M. (2012). Teaching neuroscience to science teachers: Facilitating the translation of inquiry-based teaching instruction to the classroom. CBE Life Sciences Education, 11, 413-424. doi:10.1187/cbe.12-04-0045

Ruiz-Alfonso, Z., \& León, J. (2019). Teaching quality: Relationships between passion, deep strategy to learn, and epistemic curiosity. School Effectiveness and School Improvement, 30, 212-230. doi:10.1080/09243453.2018.1562944 
Sachs, J. (2016). Accountability, standards, and activism: A challenge or opportunity for teacher education. In J. C. Lee, \& C. Day (Eds.), Quality and change in teacher education: Western and Chinese perspectives (pp. 251-262). Springer.

Sartori, G. (2009). Guidelines for concept analysis. In D. Collier, \& J. Gerring (Eds.), Concepts and method in social science: The tradition of Giovanni Sartori (pp. 97-150). Routledge:

Seidel, T., \& Shavelson, R. J. (2007). Teaching effectiveness research in the past decade: The role of theory and research design in disentangling meta-analysis results. Review of Educational Research, 77, 454- 499. doi.org/10.3102/003465430731031

Stern, B. B. (2006) What Does Brand Mean? Historical-Analysis method and construct definition. Journal of the Academy of Marketing Science, 34, 216-23. doi.org/10.1177/0092070305284991

Tahtinen, J., \& Havila, V. (2019). Conceptually confused, but on a field level? A method for conceptual analysis and its application. Marketing Theory, 19, 533-557. doi:10.1177/1470593118796677

Teacher Task Force. (n.d.). Teacher policies and practices to address education for all (EFA). http://www.teachersforefa.unesco.org/v2/phocadownload/consoldidatedcasestudies anglo phone.pdf

Thellefsen, T. (2004). Knowledge profiling: The basis for knowledge organization. Library Trends, 52, 507-514.

Wang, J., Lin, E., Spalding, E., Klecka, C. L., \& Odell, S. J. (2011). Quality teaching and teacher education: A kaleidoscope of notions. Journal of Teacher Education, 62, table331-338. doi.org/10.1177/0022487111409551

Zablotsky, B., \& Rosenberg, M. S. (2013). Special education and academic achievement. In J. Hattie, \& E. M. Anderman (Eds.), International guide to student achievement (pp. 170-172). Routledge. 